\title{
ЗАСТОСУВАННЯ КОМПЛЕКСНОГО ПІДХОДУ ЩОДО ІДЕНТИФІКАЦІЇ ТРУПІВ НЕВІДОМИХ ОСІБ В ОСОБЛИВО СКЛАДНИХ ВИПАДКАХ У ПРАКТИЦІ ЛУГАНСЬКОГО ОБЛАСНОГО БЮРО СУДОВО-МЕДИЧНОЇ ЕКСПЕРТИЗИ
}

\section{О.В. Кузьменко}

Луганське обласне бюро судово-медичної експертизи, м. Сєвєродонецьк

\section{Ключові слова: ідентифікаиія трупів невідомих осіб, комплексний nidxid. \\ Клінічна та експериментальна патологія Т.18, №2 (68). С.125-128. \\ DOI:10.24061/1727- 4338.XVIII.2.68.2019.250 \\ E-mail: smelugansk @gmail.com}

\section{Ключевые слова:} идентификачия трупов неизвестных лиц, комплексньиц подход.

Клиническая и экспериментальная патология Т.18, №2 (68). C.125-128.
Мета роботи - висвітлення та розкриття загальних проблем ідентифікаиії трупів невідомих осіб в умовах фактично триваючого військового стану в Украӥні, підняття їх на загальне обговорення та пошук шляхів їх вирішення.

Матеріал іметоди. Проведений аналіз випадків з практики стосовно ідентифікаиії трупів невідомих осіб. Об'єктом дослідження були залишки трупів та одяг.

Результати. Найбільи дієвим та результативним у випадках експертиз щзодо судово-медичної ідентифікації трупів невідомих осіб є комплексний підхід із застосуванням иентралізованого аналізу та управління за усіма етапами проведення експертизи.

Висновки. Застосування комплексного підходу надає можливість не тільки ідентифікувати невідому особу, але й на високому науковому рівні висвітлити інші судово-медичні питання, що в подальшому є основою для розслідування злочинів проти життя людини.
Key words: identification of corpses of unidentified individuals, complex approach.

Clinical and experimental pathology. Vol.18, №2 (68). P.125-128

ПРИМЕНЕНИЕ КОМПЛЕКСНОГО ПОДХОДА ПО ИДЕНТИФИКАЦИИ ТРУПОВ НЕИЗВЕСТНЫХ ЛИЦ В ОСОБО СЛОЖНЫХ СЛУЧАЯХ В ПРАКТИКЕ ЛУГАНСЬКОГО ОБЛАСНОГО БЮРО СУДЕБНО-МЕДИЦИНСКОЙ ЭКСПЕРТИЗЫ

\section{А.В. Кузьменко}

Цель работы - освещение и раскрытие общчих проблем по идентификаџии трупов неизвестных лиц в условиях фактически продолжающегося военного положения в Украине, поднятия их на всеобщее обсуждение и поиск путей по решению.

Материал и методы. Проведенный анализ случаев из практики по идентификации трупов неизвестных лиц. Объектом исследования были останки трупов и одежда. Результаты. Наиболее действенным и результативным в случаях экспертиз по судебно-медицинской идентификации неизвестных лиц является комплексный подход с применением иеентрализованного анализа и управления на всех этапах проведения экспертизы.

Выводы. Применение комплексного подхода позволяет не только идентифиицировать неизвестную личность, но и на высоком научном уровне осветить другие судебно-медицинские вопросы, что в дальнейшем служит основой для расследования преступлений против жизни человека.

\section{APPLICATION OF THE COMPLEX APPROACH TO IDENTIFICATION OF CORPSES OF UNKNOWN INDIVIDUALS IN PARTICULARLY COMPLICATED CASES IN THE PRACTICE OF LUHANSK REGIONAL BUREAU OF FORENSIC MEDICAL EXAMINATION}

\section{O.V. Kuzmenko}

The objective of the paper was to highlight and reveal common problems in the identification of corpses of unknown individuals under conditions of actually continuing military situation in Ukraine, raising them to a general discussion and finding ways to resolve them.

Material and methods. We have analyzed cases from the practice of identifying the corpses of unknown persons. The object of the study was the remains of the corpses and clothes.

Results. The most effective and useful approach in cases of forensic medical examinations of not identified individuals is a complex approach using a centralized analysis and control at all stages of the examination.

Conclusions. The use of a complex approach provides an opportunity not only to identify an unknown individual, but also to highlight other medico-legal issues at a high 
scientific level, which are the basis for investigation of crimes against the human life in the future.

\section{Вступ}

Довготривалий період, з 2014 року по теперішній час, на території України триває військовий конфлікт 3 великою кількістю загиблих в Луганській та Донецькій областях. Незаперечним фактом є превалювання насильницьких смертей як напряму пов'язаних з триваючими військовими діями, так й опосередковано зумовлених ними. Протягом 2014 року цивільне населення вимушене масово переміщуватися як через зони активних військових дій, так і через місця дислокацій військових угрупувань. Військові дії на території Луганської та Донецької областей, особливо на той час, не мали чіткого централізованого керування, що зумовлювало достатньо велику кількість протиправних злочинів проти життя людини із застосуванням вогнепальної зброї, катувань, мародерства тощо. Рештки тіл людей, що були вбиті та приховані, після упорядкування ситуації поступово знаходять і на судово-медичну експертизу покладаються складні завдання стосовно вирішення експертних питань, пов'язаних зі встановленням особи, наявності ушкоджень, давності настання смерті тощо.

\section{Мета роботи}

Відображення не стільки складного експертного випадку із практики, а й висвітлення та розкриття загальних проблем стосовно ідентифікації трупів невідомих осіб, особливо в умовах фактично військового стану, що триває в Україні з 2014 року, підняття їх на загальне обговорення та пошук шляхів їх вирішення.

\section{Матеріал і методи дослідження}

На прикладі випадку з практики, ми представимо на розгляд судово-медичної спільноти велику кількість експертних питань, які не тільки потребують особливої уваги, але й змушують нас до переходу на більш високий рівень доказової медицини.

У липні 2014 року в зоні проведення антитерористичної операції на території Луганської області подано заяву про зникнення двох чоловіків. При подальшому 3'ясуванні обставин встановлено, що їх затримали військовослужбовці. Деякий час (протягом декількох днів) вони утримувались військовими та, згідно з показами свідків, піддавалися побиттю. Один із затриманих помер, труп оглянуто фельдшером. Як з'ясувалося пізніше, його тіло було приховано поблизу, в ямі невеликої глибини. Доля іншого не встановлена (ймовірно теж загинув).

У квітні 2017 року знайдено залишки трупа та одягу, які знаходилися практично на поверхні. Огляд місця події проводився без судово-медичного експерта. Навколо місця події зібрані всі наявні кістки.

У подальшому, в травні 2017 року, проведена судово-медична експертиза та медико-криміналістична експертиза кісткових залишків та залишків одягу.

\section{Результати та їх обговорення}

Під час аналізу проведеної первинної судово-ме- дичної експертизи встановлено наявність численних недоліків, зокрема: неповний опис наданих на експертизу кісткових залишків та виявлених на них ушкоджень. Деякі кістки зовсім не описані, частина кісток зазначених як такі, що походили від тварин, були тільки перераховані. Експерти фактично порушили принцип наукового та творчого підходу до своїх обов'язків, що не надало можливість вчасно, на ранньому етапі слідчого процесу висвітлити та зафіксувати важливу інформацію. Слідчий теж не отримав консультативної допомоги зі сторони експерта стосовно додаткових досліджень вказаних речових доказів (кісткових залишків та рештків одягу), які могли б дати змогу вирішити численні питання, що виникають під час слідства.

Слідчий на свій розсуд відібрав дві кістки, які направив на молекулярно-генетичну експертизу. Експерти, що проводили молекулярно-генетичну експертизу, без будь-якого узгодження зі слідчим, відібрали для дослідження лише один кістковий об'єкт та встановили його приналежність зниклій особі, що розшукується. Тобто, з восьми кісток людини молекулярно-генетичною експертизою фактично ідентифіковано лише одну кістку.

Після вилучення кісток із безпосереднього місця їх виявлення та прилеглої навколишньої території, з нашої точки зору, слід було провести молекулярно-генетичні дослідження практично кожного об'єкта, оскільки щодо цього випадку фігурувало дві зниклі особи, а відтак і знайдені кістки могли належати їм обом. Крім того, у вказаному регіоні зареєстровано велику кількість зниклих безвісті, а повнота досліджень дає змогу ідентифікувати зниклу особу, що є важливим соціальним та моральним завданням, покладеним на державу Україну.

Нагальною проблемою стало й те, що під час первинної судово-медичної та медико-криміналістичної експертизи об'єкти дослідженні не в повному обсязі, патологічні зміни, які були наявні на кістках, вказані не повністю, трактування отриманих даних проводили некоректно (наприклад, стать, вік та зріст встановлено лише за однією стегновою кісткою).

Під час розслідування кримінального провадження, з'ясовані конкретні дані щодо часу, обставин та місця скоєння злочину. У результаті встановлено характер та механізм нанесення ушкоджень, причину смерті, місце поховання та особи, які могли були бути причетними до цього злочину. Однак судово-медичних даних виявилось недостатньо і вони були суперечливими.

3 метою всебічного вирішення численних судовомедичних питань та з'ясування істини, призначено комплексну судово-медичну експертизу, яка передбачає наявність основного координатора (голови комісіі), який не лише зможе узагальнити всі матеріали справи, а й здійснити на високому науково-технологічному рівні координацію роботи групи експертів щодо встановлення всієї інформації, яку можуть надати речові докази.

Експертизі підлягали матеріали справи, медична документація особи, якій імовірно належали кісткові

Клінічна та експериментальна патологія. 2019. Т.18, №2 (68) 
залишки (медична картка амбулаторного хворого, флюорограма, інформація про групову приналежність крові за системою АВ0), речові докази (рештки кісток та одягу).

У зв'язку з багатовекторним колом питань, до складу комісії увійшли експерти загального профілю з достатнім експертним досвідом, завідувач кафедри анатомії медичного університету, судово-медичний експерт- гістолог, судово-медичний експерт-імунолог, експерт-цитолог судовий, а також анестезіолог та рентгенолог. Експертна комісія проводила огляд речових доказів декілька разів: на підготовчому, плановому етапі; на безпосередньо дослідницькому етапі, з ретельним описом та вилученням об'єктів для подальшого гістологічного, імунологічного, цитологічного досліджень; та, задля уточнення, на підсумковому етапі.

Комплексний підхід до вивчення кісткових рештків, матеріалів справи та рештків одягу, дав можливість прийти до більш розгорнутих та детальних висновків.

За результатами комплексної експертизи, висновки розділено на дві групи: у першій з них надана експертна трактовка усіх змін, які встановлені щодо кожного кісткового об'єкта та речового доказу; у другій групі висновки мали узагальнюючий характер.

У висновках зазначено, що частина кісткових залишків (вісім кісток) належать людині. Встановлено, що під час первинної експертизи не зазначено про наявність трьох ребер та надколінка, неправильно визначено сторону приналежності кісток (змінено приналежність малогомілкової кістки з правої на ліву). На частково збережених ребрах встановлено наявність прямих та непрямих переломів, надані висновки стосовно механізму їх спричинення. У двох місцях переломів ребер встановлено наявність невеликої кількості муміфікованих м'яких тканин (розмір від 1 см х 0,5 см х 0,5 см до 0,5 cм х 0,4 cм х 0,3 cм), які вилучено для проведення судово-гістологічного дослідження та вдалося встановити наявність у вказаному місці крововиливів, що дало можливість зробити висновки про прижиттєве ушкодження ребер. Слід зазначити, що з моменту настання смерті до проведеного дослідження пройшло понад два роки. Із практики Луганського обласного бюро судово-медичної експертизи можливо зазначити, що це не перший випадок збереження крововиливів у муміфікованих м'яких тканинах. Фрагменти кісток $з$ місць ушкодження ребер також були гістологічно дослідженні та на поверхні компактної кісткової тканини встановлено наявність ознак крововиливів.

Під час імунологічного дослідження кісток, які члени експертної комісії визначили як людські, виявлений антиген А. 3 метою максимального збереження фрагментів трьох ребер вирішено провести цитологічні дослідження для встановлення видової та групової їх приналежності. Для цитологічного дослідження вилучено залишки м'яких тканин з двох ребер, а на одному ребрі зроблено зішкріб з його поверхні. Проводячи судовоцитологічне дослідження, ми встановили наявність щільної волокнистої сполученої тканини людини та антиген А. Особа, якій, можливо, належали ці кісткові рештки (вісім кісток), теж мала групову приналежність

Клінічна та експериментальна патологія. 2019. Т.18, №2 (68)
А за системою груп крові АВ0.

Під час ретельного вивченя кісткових рештків встановлено наявність ідентичних зовнішніх змін давності поховання, встановлено наявність поздовжніх тріщин від дії низьких температур, що в сукупності з іншими ознаками надало можливість прийти до висновку про їх довготривале знаходження в приблизно однакових умовах. 3 урахуванням молекулярно-генетичного, судово-імунологічного та цитологічного досліджень експертна комісія прийшла до висновку про можливу належність усіх восьми фрагментів кісток одній особі.

Під час цитологічного дослідженні фрагментів одягу, виявлено сліди поту та слини із антигеном А. Це надало можливість зробити висновок про можливе походження слідів поту та слини від особи з групою крові А $з$ ізогемаглютиніном анти-В, за серологічною системою АВ0.

Включення анатома в комісію було аналогічним до міжнародних стандартів щодо залучення судових антропологів. Лікар-рентгенолог прокоментував можливість використання флюорограми 3 метою ідентифікації в досліджуваному конкретному випадку. Лікаря анестезіолога залучено для трактовки медичної допомоги, яка надавалась затриманій особі фельдшером військової частини.

Виходячи з того, що у зв'язку із загрозою для життя в період військових дій не завжди $є$ можливість залучення фахівців у галузі судово-медичної експертизи у невідкладних слідчих діях, є пропозиція про необхідність відновлення військової судово-медичної експертизи Міністерства оборони України або використання фахівців місцевих бюро з надання їм відповідного статусу службовців, що залучаються до обслуговування потреб проведення військових дій [1-3].

\section{Висновки}

1. Найбільш дієвим та результативним у випадках експертиз щодо судово-медичної ідентифікації невідомих осіб $є$ комплексний підхід із застосуванням централізованого аналізу та управління за усіма етапами проведення експертизи.

2. Застосування комплексного підходу надає можливість не тільки ідентифікувати невідому особу, але й на високому науковому рівні висвітлити інші судовомедичні питання, що в подальшому є основою для розслідування злочинів проти життя людини.

3. Молекулярно-генетичні методи дослідження слід використовувати як додаткові та у більшості випадків у комплексі з іншими методами діагностики.

4. Для ефективної реалізації комплексного підходу щодо ідентифікації невідомих осіб весь комплекс досліджень слід проводити за місцем знаходження трупа, тобто з практичної та наукової точки зору кожне обласне бюро України на теперішній час повинно мати обладнання для молекулярно-генетичних досліджень.

\section{Перспективи подалыших досліджень}

Удосконалення вже існуючого підходу по ідентифікації трупів невідомих осіб шляхом впровадження у практичну діяльність комплексного методу дослідження.

ISSN 1727-4338 https://ww.bsmu.edu.ua 


\section{Список літератури}

1. Козьяков Р. Розслідування безвісного зникнення особи як теоретична та прикладна проблема. Науковий часопис Національної академії прокуратури України [Інтернет]. 2014[цитовано 2019 Бер 29];4:84-95. Доступно: http://www.chasopysnapu.gp. gov.ua/ua/pdf/4-2015/koziakov.pdf

2. Мішалов ВД, Хохолєва ТВ, Бачинський ВТ, Войченко ВВ, Кривда ГФ, Костенко ЄЯ. Судова медицина. Київ; 2018. 575 c.

3.Филипчук ОВ, Гуров ОМ. Судово-медична криміналістика. Харків: Діса плюс; 2013. 639 с.

\section{References}

1.Koziakov R. Rozsliduvannia bezvisnoho znyknennia osoby yak teoretychna ta prykladna problema [Investigation in case of persons gone missing as a theoretical and applied problem]. Scientific journal of the National prosecution academy of Ukraine [Internet]. 2014[tsytovano 2019 Ber 29];4:84-95. Dostupno: http: //www.chasopysnapu.gp.gov.ua/ua/pdf/4-2015/koziakov.pdf (in Ukrainian).

2.Mishalov VD, Khokholieva TV, Bachyns'kyi VT, Voichenko VV, Kryvda HF, Kostenko YeIa. Sudova medytsyna [Forensic Medicine]. Kiev; 2018. 575 p. (in Ukrainian).

3.Fylypchuk OV, Hurov OM. Sudovo-medychna kryminalistyka [Ship-medical criminality]. Kharkiv: Disa plius; 2013. 639 p. (in Ukrainian).

\section{Відомості про автора:}

Кузьменко О.В. - т.в.о. начальника Луганського обласного бюро судово-медичної експертизи, м. Сєвєродонецьк, Україна

\section{Сведения об авторе:}

Кузьменко А.В. - в.и.о. начальника Луганского областного бюро судебно-медицинской экспертизы, г. Северодонецк, Украина

Information about author:

Kuzmenko O.V. - Acting Head of Luhansk Regional Office of Forensic Medical Examinations, Severodonetsk, Ukraine 